\title{
Biology of Vampyressa pusilla (Wagner) in Rio de Janeiro State, Southeastern Brazil (Mammalia, Chiroptera, Phyllostomidae)
}

\author{
Esbérard, CEL. ${ }^{\text {* }}$ and Bergallo, $H G{ }^{\mathrm{b}}$ \\ aLaboratório de Diversidade de Morcegos, Instituto de Biologia, \\ Universidade Federal Rural do Estado do Rio de Janeiro - UFRJ, \\ CP 74507, CEP 23851-970, Seropédica, Rio de Janeiro, Brazil \\ bDepartamento de Ecologia, Instituto de Biologia Roberto Alcântara Gomes - IBRAG, \\ Universidade do Estado do Rio de Janeiro - UERJ, Rua São Francisco Xavier, 524, \\ CEP 20559-900, Rio de Janeiro, RJ, Brazil \\ *e-mail: cesberard@superig.com.br
}

Received January 1, 2008 - Accepted April 4, 2009 - Distributed May 31, 2010

(With 5 figures)

\begin{abstract}
Vampyressa pusilla is widespread in Rio de Janeiro State, southeastern Brazil. It occurs in forested areas, and is absent from urban and open habitats. This species occurs mainly in altitudes up to 1,300 $\mathrm{m}$ a.s.l. Vampyressa pusilla was captured during the whole night, from 18 minutes before sunset to 759 minutes after sunset. Captures peaked in the first two hours of the night. Reproductive activity was seasonal, pregnant females were observed in January, February, April, August, October, November and December and lactating females from November to January and in March.
\end{abstract}

Keywords: abundance, activity, reproduction, distribution, record.

\section{Biologia de Vampyressa pusilla (Wagner) no Estado do Rio de Janeiro, Sudeste do Brasil (Mammalia, Chiroptera, Phyllostomidae)}

\begin{abstract}
Resumo
Vampyressa pusilla tem uma larga distribuição no Estado do Rio de Janeiro, sudeste do Brasil. Pode ser encontrada em florestas, mas não em áreas urbanas nem em paisagens abertas. Esta espécie ocorre de 0 a $1300 \mathrm{~m}$ de altitude. Vampyressa pusilla foi capturada por toda a noite, desde 18 minutos antes do pôr-do-sol até 759 minutos após o pôr do sol. A frequência de captura foi maior dentro das duas primeiras horas. A atividade reprodutiva é estacional, com fêmeas grávidas observadas em janeiro, fevereiro, abril, agosto, outubro, novembro e dezembro e fêmeas lactantes de novembro a janeiro e março.
\end{abstract}

Palavras-chave: abundância, atividade, distribuição, reprodução, registro.

\section{Introduction}

The genus Vampyressa Thomas, 1900 has four species that occur in Brazil, three of them restricted to the northern region (Simmons, 2005). Two subspecies of Vampyressa pusilla (Wagner, 1843) were recognised only recently: V. p. pusilla, in southern Brazil and adjacent areas, and V. p. thyone Thomas 1909, in Mexico, Bolivia, Peru, Venezuela and Guianas. The latter was considered as another species based on morphological, genetic and molecular differences (Lim et al., 2003). According to Handley (1976), V. thyone is found mainly $(86 \%)$ at high altitudes (over $500 \mathrm{~m}$ a.s.1.) in Venezuela and it was collected from 300 to $1500 \mathrm{~m}$ a.s.l. in Peru (Graham, 1983).

Vampyressa pusilla occurs in southern Brazil, Paraguay and northern Argentina (Myers et al., 1983;

Lewis and Wilson, 1987; Koopman, 1993; Pedro et al., 1997; Barquez et al., 1999; Pedro et al., 2001; Lim et al., 2003; Bianconi et al., 2004). Vampyressa pusilla, as with other stenodermatines, is a predominantly frugivorous species (Gardner, 1977) and it is considered as a Ficus specialist (Lewis and Wilson, 1987; Pedro et al., 1997; Giannini and Kalko, 2004). Vampyressa pusilla, as other congeneric species, uses leaves transformed into tents as day roosts (e.g. Timm, 1984; Brooke, 1987; Zortéa and Brito, 2000). Small groups, composed of one male and a few females, can occupy tents for up to six months (Kunz et al., 1994). This bat exhibits seasonal reproduction: females give birth once or twice during each reproductive season. However, the available reproductive 
information for this species is still scarce and incomplete (Wilson, 1979; Lewis and Wilson, 1987).

This bat is considered to occur in low abundance in the Atlantic Forest, because it is represented by only a few captures, and this characteristic is attributed to its specialised feeding habit (e.g. Pedro et al., 2001; Passos et al., 2003; Bianconi et al., 2004).

During long-term sampling carried out in Rio de Janeiro State from 1988 to 2008, some aspects of the biology of $V$. pusilla were recorded and are presented in this study.

\section{Material and Methods}

Bats were captured with mist nets opened on trails or in gaps inside forests, close to fruiting trees, or close to water bodies. Nets were kept open from sunset to sunrise, and were checked at intervals of 20 minutes on average (e.g. Esbérard, 2003). Between April 1989 and April 2008, a large and representative sample of bats (954 nights, 10,494 hours of sampling with nets in 71 different localities and 30,554 captures and recaptures) was conducted in Rio de Janeiro State. In this sampling, man-altered areas were analysed, such as plantations, backyards and urban parks, as well as secondary and pristine forests. Sampling was not concentrated in any particular lunar phase. The time of capture for each individual bat was recorded and converted into minutes after local sunset time. Sunset times were obtained from the database of the National Observatory of Rio de Janeiro, Brazil.

Body mass of bats was measured with spring scales $(0.1 \mathrm{~g})$ and forearm length was measured with digital calipers $(0.1 \mathrm{~mm})$. Each individual bat was assigned to one of the following reproductive categories: (1) females - inactive, pregnant with palpable fetus, lactating, with retreated nipples, or simultaneously pregnant and lactating; (2) males - testes in abdomen or testes in scrotum. Age of individual bats was estimated based on the ossification of the epiphyses (Anthony, 1988) and fur coloration. Most bats were marked with colored plastic ball-chain necklaces (Esbérard and Daemon, 1999) and released immediately after marking. Voucher specimens were deposited in the collection of Projeto Morcegos Urbanos at Universidade Federal Rural do Rio de Janeiro (Process 1755/89 IBAMA-DEVIS/RJ).

Differences in forearm length and weight between females and males analysed were tested using a t-test. Simple linear regressions (Zar, 1996) were used to test the relationship between percentage of captures of $V$. pusilla and altitude in the 41 best-sampled localities (over 200 captures). We used a Kruskal-Wallis test (Zar, 1996) to compare the percentage of $V$. pusilla captures at localities where part of the sampling nights were accomplished near fruiting fig trees and localities where mist nets were opened far from fig trees.

\section{Results and Discussion}

Seventy one individuals of $V$. pusilla were captured in 28 of the 71 localities sampled $(39.4 \%)$ (Figure 1). The species was absent from open areas such as coastal shrublands ('restingas'), mangroves, urban areas, pastures and orchards. Approximately $90 \%$ of the captures were obtained near forest edges, and the rest were observed in banana plantations or over water bodies.

Vampyressa pusilla represented $1.05 \pm 1.19 \%$ (mean \pm sd, varying from 1.06 to $5.67 \%$ ) of all captures, and so may be considered as uncommon at all localities. Vampyressa pusilla was observed at altitudes from sea level to $1,300 \mathrm{~m}$ a.s.l. There was no relationship between the percentage of captures and the altitude for each locality (Figure 2) $(r=0.06, p=0.66)$.

This bat species was netted close to four fruiting fig species: Ficus tomentella Miquel, F. citrifolia Mill, F. lutea Vahl and F. enormis (Miq.) Miq., but capture frequency at those sites (0-3 captures/night) was not significantly different than at other sites where the nets were set (0-4 captures/night) $(\mathrm{U}=56,00, \mathrm{p}=0,36)$.

Among all 71 individuals analysed, 37 were males $(52 \%)$. Bats with testes in scrotum comprised $19 \%$ of all male captures $(\mathrm{N}=7)$ and were observed in January, April, May, July and November (Figure 3). Among females (48\%), we confirmed the pregnancy (with palpable fetus) in January, February, April, August, October, November and December, with a peak in January $(\mathrm{N}=6)$. Lactating females were netted during January, March, November, and December and females simultaneously pregnant and lactating were captured in January (Figure 3). Bats with incomplete ossification of the epiphyses were captured in February $(\mathrm{N}=1)$, April $(\mathrm{N}=3)$, May $(\mathrm{N}=5)$, June $(\mathrm{N}=2)$ and September $(\mathrm{N}=1)$. Wilson (1979) described a polyoestric bimodal pattern of reproduction for $V$. thyone, including births occurring during the rainy season. Pregnant females of this species were observed in the northern hemisphere in January, February, March, April and May, whereas in the southern hemisphere also in August and November. Pedro et al. (1997) found a pregnant female in October in southern São Paulo State. The capture of pregnant females in April and August suggests a large breeding season as recently described for Platyrrhinus lineatus (E. Geoffroy, 1810) (Costa et al., 2007). The breeding season of V. pusilla is similar to other frugivorous species at the same latitude (e.g. Taddei, 1976; Mello and Fernandez, 2000; Costa et al., 2007), with maximum peak of capture of reproductive females in the rainy months and a smaller one in the early dry season (see Mello and Fernandez, 2000).

Forearm length varied between $30.50 \mathrm{~mm}$ and $34.97 \mathrm{~mm}(33.00 \pm 0.96 \mathrm{~mm})$, and we observed a significant difference between the sexes $(\mathrm{t}=2.40, \mathrm{df}=68$, $\mathrm{p}=0.02)$, with females bigger $33.21 \pm 0.81 \mathrm{~mm}(\mathrm{~N}=34)$ than males $32.83 \pm 1.05 \mathrm{~mm}(\mathrm{~N}=35)$ (Figure 4). Body mass varied from 6.0 to $17.0 \mathrm{~g}(10.49 \pm 2.40 \mathrm{~g})$, scor- 


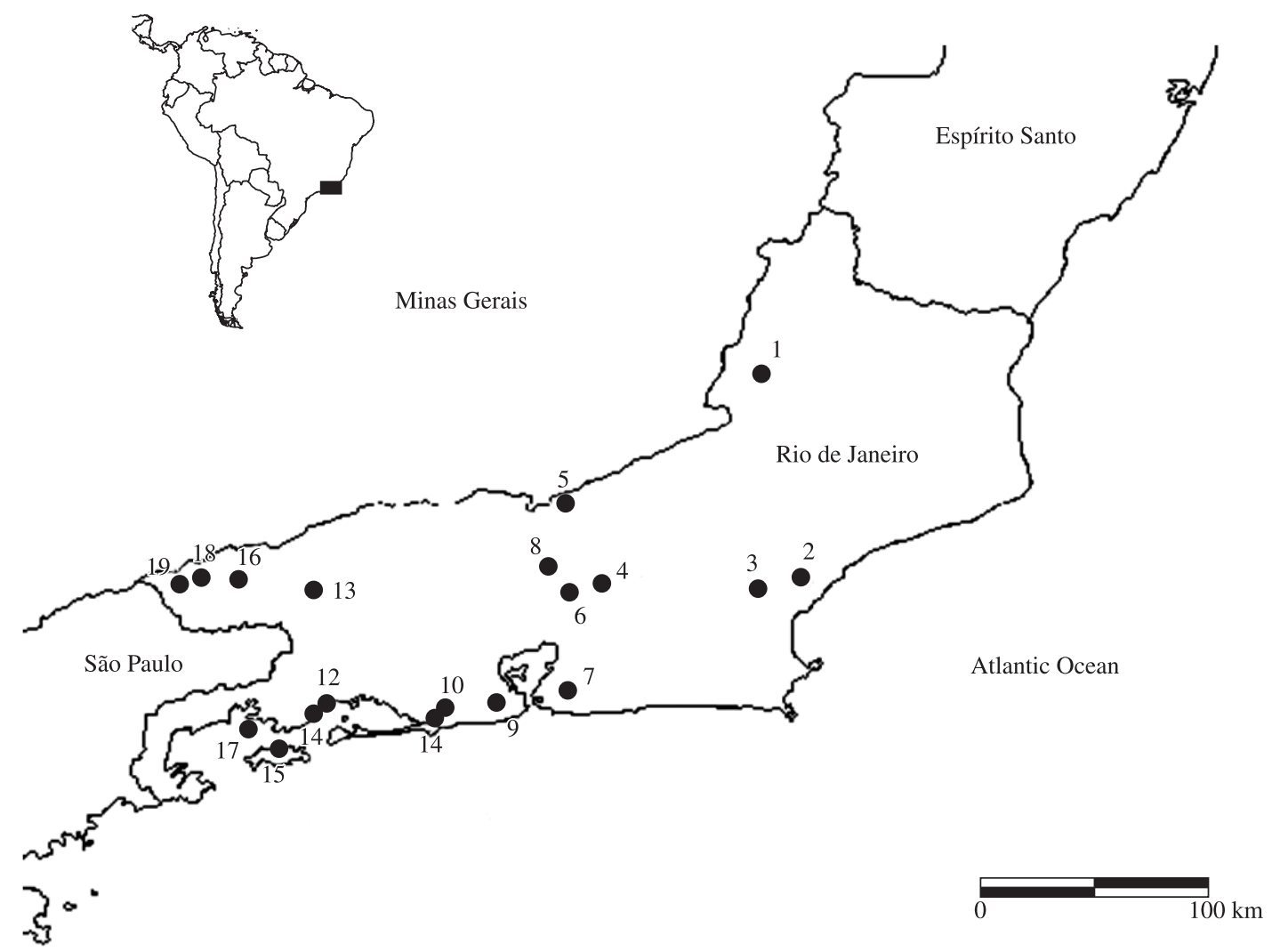

Figure 1. Localities in Rio de Janeiro State where Vampyressa pusilla was recorded - (1) Fazenda Prosperidade, Miracema; (2) Morro de São João, Casimiro de Abreu; (3) Reserva Biológica de Poço das Antas, Silva Jardim; (4) Reserva Ecológica de Guapiaçú, Guapiaçú; (5) AHE Mello, Rio Preto; (6) Estação Ecológica Estadual Paraíso, Guapimirim; (7) Reserva Estadual Serra da Tiririca, Niterói; (8) Reserva Biológica de Araras, Petrópolis; (9) Maciço da Tijuca (Açude da Solidão, APA do Alto Boa Vista, Convento das Carmelitas, Parque Henrique Lage, Jardim Botânico, Reserva do Horto Florestal, Parque do Penhasco Dois Irmãos, Reserva dos Trapicheiros, Parque da Gávea, Reserva Florestal do Grajaú, APA São Judas Tadeu, APA de São Conrado), Rio de Janeiro; (10) Parque Estadual da Pedra Branca, Rio de Janeiro (Dias et al., 2002); (11) Sítio Burle Marx, Rio de Janeiro; (12) Fazenda Portobello, Mangaratiba; (13) Fazenda Antas, Paty do Alferes; (14) Reserva Rio das Pedras, Mangaratiba; (15) Ilha Grande, Angra dos Reis; (16) Santuário Serra da Concórdia, Valença; (17) Ilha da Gipóia, Angra dos Reis; (18) Fazenda Marimbondo, Visconde de Mauá; (19) Parque Nacional do Itatiaia, Itatiaia (Ávila-Pires and Gouveia, 1977).

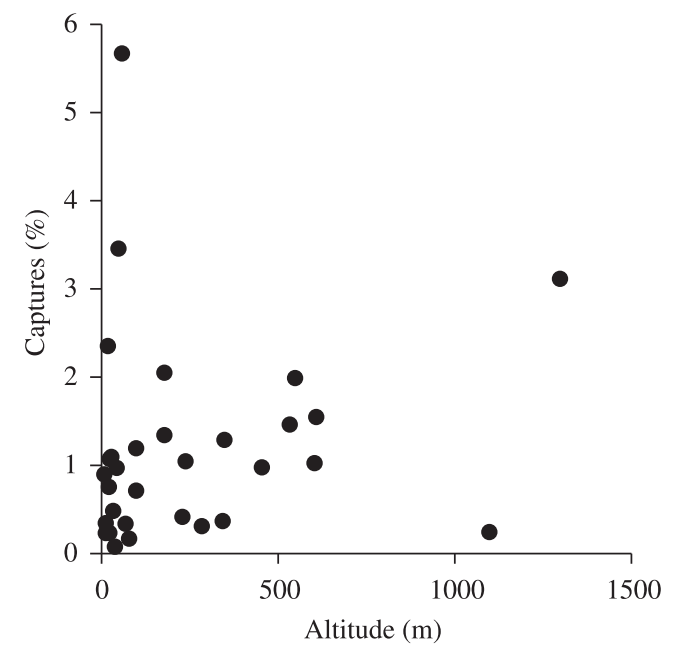

Figure 2. Relationship between the frequency of captures of Vampyressa pusilla and the altitude in all localities studied. ing $11.71 \pm 2.26 \mathrm{~g}$ for females without palpable fetuses $(\mathrm{N}=27)$ and $10.29 \pm 2.13 \mathrm{~g}$ for males $(\mathrm{N}=33)$, and this difference was not significant $(\mathrm{t}=1.56, \mathrm{df}=59, \mathrm{p}=0.13)$. Pedro et al. (1997) and Dias et al. (2002) reported similar measurements of forearm length for V. pusilla in the states of São Paulo and Rio de Janeiro.

This species was captured from sunset to sunrise (from 18 before sunset to 759 minutes after sunset), with a peak during the first two hours of the night (Figure 5). Pedro and Taddei (2002) obtained similar results on five phyllostomid bats in southeastern Brazil. In the present study, among the analysed captures, $57 \%$ were observed prior to six hours after sunset, and the average time for all captures was 130 minutes after sunset. Activity of frugivorous bat species is longer than other species of bats that have high-energy diets, such as carnivorous and insectivorous bats (Bernard, 2002). Most frugivorous species studied so far, presented all-night long activity with 

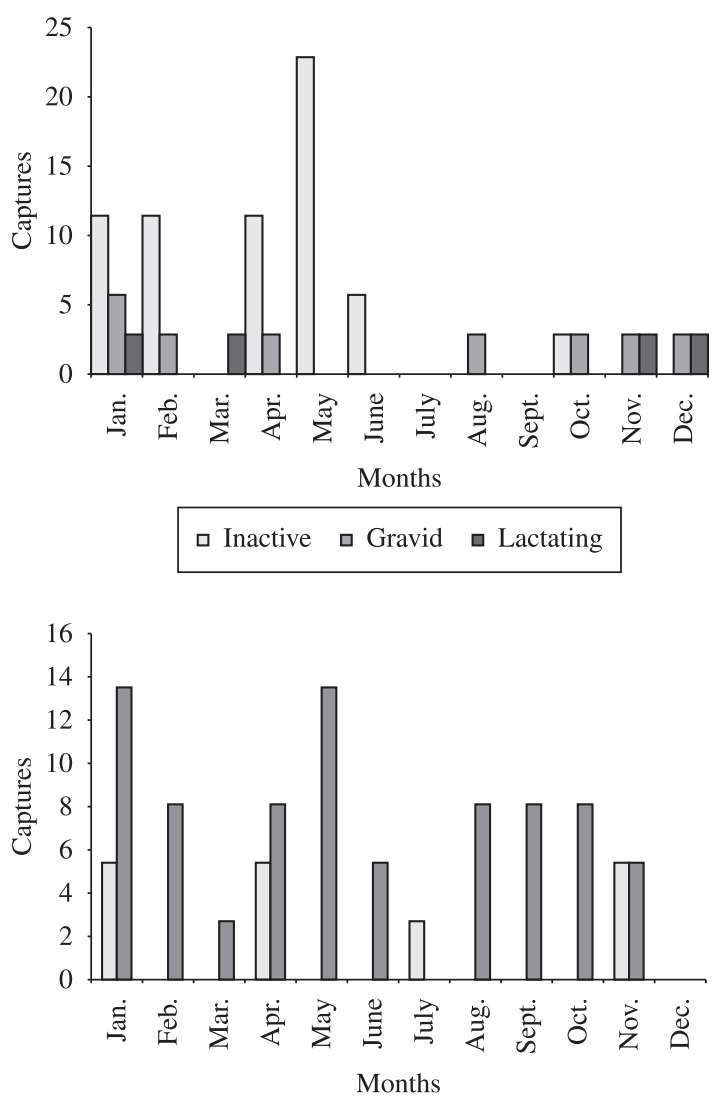

$\square$ Abdominal testes $\square$ Descend testes

Figure 3. Number of captures of females and males of Vampyressa pusilla divided into different reproductive categories.

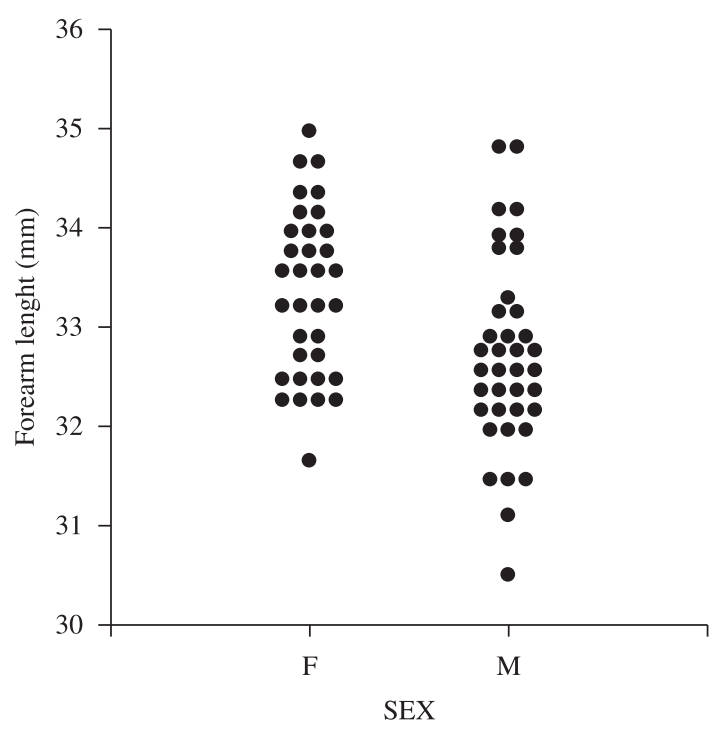

Figure 4. Variability of forearm length in males and females of Vampyressa pusilla.

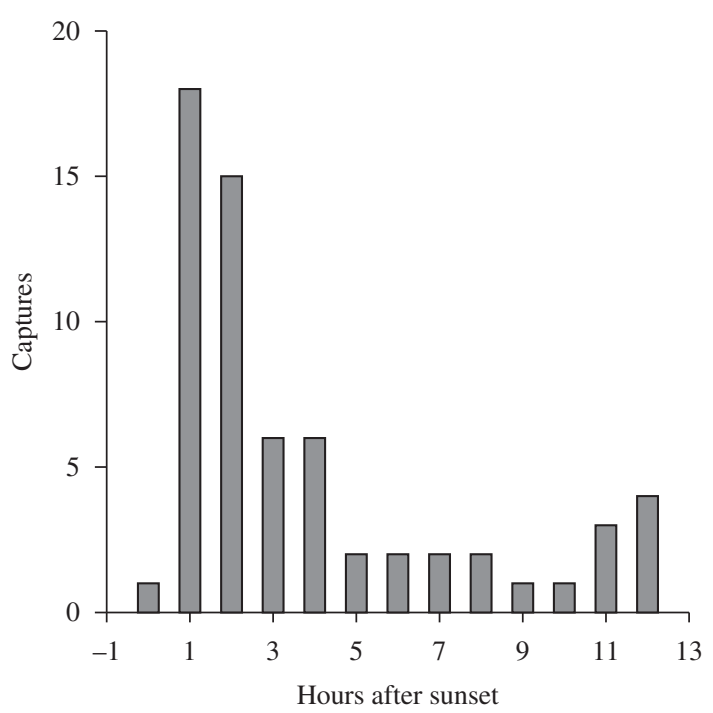

Figure 5. Distribution of captures of Vampyressa pusilla according to hours after sunset.

higher frequency of capture during the first hours after sunset (e.g. Erkert, 1982).

Vampyressa pusilla is a widely distributed species in the State of Rio de Janeiro, and can be found in altitudes from sea level to $1,300 \mathrm{~m}$ a.s.l. However, it is not more frequent at higher altitudes, as affirmed by Handley (1976) for $V$. thyone. This bat is restricted to forest areas and surroundings, and seems to be rarely netted even in the canopy (Bernard, 2001). In all localities studied $V$. pusilla occurred at low density, even when samplings were carried out close to fruiting fig trees.

Acknowledgements - We would like to thank Instituto Estadual de Florestas, Instituto Brasileiro de Meio Ambiente, Centro de Primatologia do Rio de Janeiro/FEEMA, Fazendas Reunidas São João, Fazenda da Barra, Reserva Guapiaçú, Reserva Ecológica Rio das Pedras, Secretaria Municipal de Meio Ambiente do Município do Rio de Janeiro and Secretaria de Agricultura e Pesca de Casimiro de Abreu and owners of the areas where attacks of vampire bats were recorded (13 localities). Davor Vrcibradic helped to translate the text into English. The special sampling license was provided by IBAMA (Processes 1785/89-IBAMA and 4156/95-46 AC-SUPES/DF/IBAMA to C.E.L. Esbérard). Financial support was provided by the Fundo de Conservação Ambiental/SMAC (Process 14/001.917/97 for 6 localities), Critical Ecosystem Partnership Fund (CEPF Aliança para Conservação da Mata Atlântica- CI - Brazil / SOS Mata Atlântica for 2 localities), Instituto Biomas (2 localities), CEADS/Universidade do Estado do Rio de Janeiro (1 local) and FAPERJ (E-26/170.449/07 for 6 localities). C.E.L. Esbérard received a productivity fellowship from $\mathrm{CNPq}$ (301061/2007-6) and H.G. Bergallo a productivity fellowship from $\mathrm{CNPq}$ (301372/95-0) and Prociência/UERJ.

\section{References}

ANTHONY, ELP., 1988. Age determination in bats. In KUNZ, TH. (Ed). Ecological and behavioral methods for the study of bats. Washington: Smithsonian Institution Press. p. 47-58. 
ÁVILA-PIRES, FD. and GOUVEIA, E., 1977. Mamíferos do Parque Nacional de Itatiaia. Boletim do Museu Nacional, vol. 291, no.1, p. 1-29. (Nova Série Zoológica)

BARQUEZ, RM., MARES, MA. and BRAUN, JK., 1999. The bats of Argentina. Texas: Museum Texas Tech University. p. 1-275. (Special Publications, 42).

BERNARD, E., 2001. Vertical stratification of bat communities in primary forests of Central Amazon, Brazil. Journal of Tropical Ecology, vol. 17, no. 1, p. 118-126.

BERNARD, E., 2002. Diet, activity and reproduction of bat species (Mammalia, Chiroptera) in Central Amazonia, Brazil. Revista Brasileira de Zoologia, vol. 19, no. 1, p. 173-188.

BIANCONI, GV., MIKICH, SB. and PEDRO, WA., 2004. Diversidade de morcegos (Mammalia,Chiroptera) em remanescentes florestais do município de Fênix, noroeste do Paraná, Brasil. Revista Brasileira de Zoologia, vol. 21, no. 4, p. $943-954$

BROOKE, AP., 1987. Tent construction and social organization in Vampyressa nymphaea (Chiroptera: Phyllostomidae) in Costa Rica. Journal of Tropical Ecology, vol. 3, no. 2, p. 171-175.

COSTA, LM., ALMEIDA, JC. and ESBÉRARD, CEL., 2007. Reprodução de Platyrrhinus lineatus (Geoffroy) no Estado do Rio de Janeiro, Sudeste do Brasil (Mammalia: Phyllostomidae). Iheringia, Série Zoologia, vol. 97, no. 2, p. 152-156.

DIAS, D., SILVA, SSP. and PERACCHI, AL., 2002. Quirópteros do Parque Estadual da PedraBranca, Rio de Janeiro, RJ (Mammalia: Chiroptera). Revista Brasileira de Zoologia, vol. 19 , no. 2 , p. 113-140.

ERKERT, HG., 1982. Ecological aspects of bat rhythms. In KUNZ, TH. (Ed.). Ecology of bats. New York: Plenum Press. p. 201- 242 .

ESBÉRARD, CEL., 2003. Diversidade de morcegos em uma área de Mata Atlântica regenerada no sudeste do Brasil (Mammalia: Chiroptera). Revista Brasileira de Zoociências, vol. 5, no. 2, p. 189-204.

ESBÉRARD, CEL. and DAEMON, C., 1999. Novo método para marcação de morcegos. Chiroptera Neotropical, vol. 5, no. 1-2, p. 116-117.

GARDNER, AL., 1977. Feeding habits. In BAKER, RJ., KNOX JONES Jr., J. and CARTER, DC. (Eds.). Biology of bats of the New World family Phyllostomidae. Texas: Museum Texas Tech University. p. 293-350. (Part II, Special Publications, 13)

GIANNINI, NP. and KALKO, EKV., 2004. Trophic structure in a large assemblage of phyllostomid bats in Panama. Oikos, vol. 105 , no. 2 , p. 209-220.

GRAHAM, GL., 1983. Changes in bat species diversity along an elevational gradient up to Peruvian Andes. Journal of Mammalogy, vol. 64, no. 4, p. 559-571.

HANDLEY, Jr., CO., 1976. Mammals of the Smithsonian Venezuelan Project. Brigham Young University Science Bulletin, vol. 20, no. 5, p. 1-91. (Biological Series)

KOOPMAN, KF., 1993. Order Chiroptera. In WILSON, DE. and REEDER, DM. (Eds.). Mammal species of the World: a taxonomic and geographic reference. 2 ed. Washington: Smithsonian Institution Press. p. 137-241.
KUNZ, TH., FUJITA, MS., BROOKE, AP. and MCCRACKEN, GF., 1994. Convergence in tent architecture and tent-making behavior among neotropical and paleotropical bats. Journal of Mammalian Evolution, vol. 2, no. 1, p. 57-78.

LEWIS, SE. and WILSON, DE., 1987. Vampyressa pusilla. Mammalian Species, no. 292, p. 1-5.

LIM, BK., PEDRO, W. and PASSOS, FC., 2003. Differentiation and species status of the Neotropical yellow-eared bats Vampyressa pusilla and $V$. thyone (Phyllostomidae) with a molecular phylogeny and review of the genus. Acta Chiropterologica, vol. 5, no. 1, p. 15-29.

MELLO, MAR. and FERNANDEZ, FAZ., 2000. Reproductive ecology of the bat Carollia perspicillata (Chiroptera: Phyllostomidae) in a fragment of the Brazilian Atlantic Coastal forest. Zeitschrift für Säugetierkunde, vol. 65, no. 5, p. 340-349.

MYERS, P., WHITE, R. and STALLINGS, J., 1983. Additional records of bats from Paraguay. Journal of Mammalogy, vol. 64, no. 1, p. 143-145.

PASSOS, FC., SILVA, WR., PEDRO, WA. and BONIN, MR., 2003. Frugivoria em morcegos (Mammalia, Chiroptera) no Parque Estadual Intervales, sudeste do Brasil. Revista Brasileira de Zoologia, vol. 20, no. 3, p. 511-517.

PEDRO, WA., CARVALHO, C., HAYASHI, MM., BREDT, A., ARMANI, NMS., SILVA, MMS., GOMES, L., GONÇALVES, CA. and PERES, NF., 1997. Notes on Vampyressa pusilla (Wagner, 1843) in the south of São Paulo State. Chiroptera Neotropical, vol. 3, no. 2, p. 79-80.

PEDRO, WA., PASSOS, FC. and LIM, BK., 2001. Morcegos (Chiroptera; Mammalia) da Estação Ecológica dos Caetetus, Estado de São Paulo. Chiroptera Neotropical, vol. 7, no. 1-2, p. $136-140$.

PEDRO, WA. and TADDEI, VA., 2002. Temporal distribution of five bat species (Chiroptera, Phyllostomidae) from Panga Reserve, South-eastern Brazil. Revista Brasileira de Zoologia, vol. 19, no. 3, p. 951-954.

SIMMONS, NB., 2005. Order Chiroptera. In WILSON, DE. and REEDER, DM. (Eds.). Mammalspecies of the World: a taxonomic and geographic reference. 3 ed. Baltimore: Johns Hopkins University Press. p. 312-529.

TADDEI, VA., 1976. The reproduction of some Phyllostomidae (Chiroptera) from the northwestern region of the state of São Paulo. Boletim de Zoologia da Universidade de São Paulo, vol. 1, p. 313-330.

TIMM, RM., 1984. Tent construction by Vampyressa in Costa Rica. Journal of Mammalogy, vol. 65, no. 1, p. 166-167

WILSON, D., 1979. Reproductive patterns. In BAKER, RJ., JONES, JK. and CARTER, DC. (Eds.). Biology of bats of the new world family Phyllostomidae. Texas: Museum Texas Tech University. p. 317-78. (Part I, Special Publications, 10)

ZAR, JH., 1996. Biostatistical analysis. 3 ed. New Jersey: Prentice-Hall. 662 p.

ZORTÉA, M. and BRITO, BFA., 2000. Tents used by Vampyressa pusilla (Chiroptera: Phyllostomidae) in southeastern Brazil. Journal of Tropical Ecology, vol. 16, no. 3, p. 475-480. 
